\title{
Ubiquitination Regulation Protein
}

National Cancer Institute

\section{Source}

National Cancer Institute. Ubiquitination Regulation Protein. NCI Thesaurus. Code C95242.

A protein that plays a role in the regulation of ubiquitination of other proteins and, subsequently, modulates the targeting of proteins for degradation by the proteasome. 